\title{
ISLAMIC BANKING PERFORMANCE MEASUREMENT: A CONCEPTUAL REVIEW OF TWO DECADES
}

\author{
Elyanti Rosmanidar \\ Faculty of Islamic Economic and Business \\ Universitas Islam Negeri Sulthan Thaha Saifuddin Jambi, Indonesia \\ E-mail: elyantirosmanidar@uinjambi.ac.id \\ Abu Azam Al Hadi \\ Universitas Islam Negeri Sunan Ampel Surabaya, Indonesia \\ E-mail: abuazam1958@gmail.com \\ Muhamad Ahsan \\ Universitas Islam Negeri Sunan Ampel Surabaya, Indonesia \\ E-mail: m.ahsan@uinsby.ac.id
}

\begin{abstract}
This article aims to provide an overview of the development of research on the measurement of Islamic banking performance over the past 20 years from 89 selected papers with Scopus-indexed journals ranked Q4 to Q1 or accredited with Sinta 2 to Sinta 1. This study used a qual-quantitative meta-analysis approach using the Mendeley citation application. The distribution of the topic and the depth of research in paper samples based on keywords in publications were analyzed using the VOSviewer application. The results of the analysis showed that the research trend of Islamic banking performance in reputable journals is increasing in recent years. Most of the studies performed in the last two decades have focused on the practice and corporate governance of Islamic banks and comparisons between Islamic and conventional banks based on financial performance ratios and aspect of maqasid al-Shariah; Only a few studies that discuss efficiency, social performance on Islamic banks, regulation, intellectual capital and stability of the financial performance of Islamic banks were found. The further discussion is an empirical exposure without theoretical exploration or analysis which is supposed to become the direction of banking research in the future.
\end{abstract}

Keywords: Performance, Islamic Bank, Maqasid al-Shariah, Literature Review, VOSviewer.

JEL Classification Codes: G21, L25, P17, P47.

\section{INTRODUCTION}

Islamic banks come to answer the risk of endemic financial transactions that occur in the world (Hassan \& Aliyu, 2018). Various studies found that interest, gambling, speculation, and derivative transactions, all of which are prohibited in the principles of Islamic law adhered to by Islamic banks, are factors that cause financial crises (Akber \& Dey, 2020; Hassan \& Aliyu, 2018; Khan, 2010). Besides, several studies revealed that Islamic banks as competitors of conventional ones had become a diversion in the financial world to sustain a country's resilience to exogenous shocks caused by the global financial crisis (Alexakis et al., 2019; Beck et al., 2013; Berger et al., 2019). Islamic banking and Islamic finances serve as alternative solutions and models to face the global financial crisis.

Islamic banks as business entities and their development need to be assessed by performance measurement. Targets, goals, and future activities are set arranged by management by looking at the 
results of previous performance measurements. The assessment of the banks' health is carried out based on performance measurement, which is a significant parameter (Nurindrasari et al., 2018).

The most relevant and popular parameters used to measure banking performance in the world, including in measuring Islamic banks' performance, are Capital, Asset Quality, Management, Earnings, and Liquidity and Sensitivity to Market Risk (CAMELS), as recommended by the IMF and the World Bank (Keffala, 2020). Besides, Economic Value Added (EVA), Balance Score Card (BSC), and Data Envelopment Analysis (DEA) are parameters widely used in measuring Islamic banking performance (Maharani \& Rahmawati, 2020), as used in measuring conventional banks' performance.

The application of traditional measuring instruments in Islamic banks has drawn a lot of criticism from academics who consider them inappropriate given that Islamic banks and conventional banks have different characteristics. The Islamic values require Islamic banks, in addition to achieving operational profit, to uphold the principles of justice and brotherhood and distribute income and wealth for social welfare (Dusuki, 2008). In the other words, Islamic banks' performance is not only limited to financial aspects but also to their attention to social and $d a^{\prime}$ wah aspects in the environment in which they operate (Adib \& Khalid, 2010; Maharani \& Rahmawati, 2020; Triyuwono, 2011). Traditional performance measurement tools are considered to fail in describing the parameter Shariah compliance which can even worsen the social image of Islamic banks (Hudaefi \& Noordin, 2019; Maharani \& Rahmawati, 2020). Based on these reasons, several researchers, including Hudaefi and Noordin (2019) and Triyuwono (2011) compiled performance measurement tools that are considered appropriate to the characteristics of Islamic banks.

Hitherto, various performance measurement methods have been applied to Islamic banks. Neely (1999) said that performance measurement could be seen from sundry sides, and there is no one best way to measure business performance. This article attempts to document the development of research on the performance measurement of Islamic banks over 20 years from various aspects such as comparison of Islamic banks with their counterparts (Witjaksono \& Yunistriani, 2011), Islamic banking performance with multiple perspectives, such as maqasid al-sharia and sharia enterprise theory, social reporting on the financial performance of Islamic banks (Arifin \& Wardani, 2016; Farag et al., 2018; Sofyani et al., 2012), efficiency and stability (Mukhlis, 2012; Pramuka, 2011; Sufian, 2007), good corporate governance and sharia governance of Islamic banks, comparison between Islamic banks and conventional banks (Erol et al., 2014; Olson \& Zoubi, 2008), intellectual capital on the performance of Islamic banks (Lestari et al., 2016), and measurement of Islamic banking performance with different goals.

This article would give a contribution in, first, mapping research topics regarding performance measurement in Islamic banking based on various aspects and variables and, secondly, providing an overview for researchers in choosing research themes related to the next performance measurement of Islamic banks.

\section{METHOD}

This research was descriptive qualitative-quantitative using meta-analysis and content analysis. To help explain the distribution of topics and the depth of research, the authors used the VOSviewer application version 1.6.16. At the initial stage, the search for sample articles was carried using relevant keywords and synonyms, namely: "Islamic Banking Performance", "Islamic Banks Performance Measured", and others. Furthermore, the selected documents were revised based on titles, abstracts, keywords, and papers that discussed subjects considered theoretically relevant. We used the Mendeley application to prepare the meta-data for these articles. The criteria for selecting these articles were, first, journals published in 2000-2020; secondly, Scopus-indexed journals ranked Q4 to Q1 or accredited with Sinta 2 to Sinta 1 with the number of citations in five years of 
above 1000, and; thirdly, journals accessible online through the Science Direct, emerald insight, and Google Scholar site.

As many as 100 papers on the Islamic bank's performance measurement were selected. The earliest sample article was published in 2003. This was thought to happen because Islamic banks started to develop rapidly since the occurrence of the 1998 economic crisis. So, research on the performance of Islamic banking began to be performed effectively in 2003. Based on the year of publication, Islamic banking performance was not a popular topic in reputable journals before 2009 . The research trend on Islamic banks' performance began to increase in 2010 until it reached the highest number of articles in 2018, namely 13 papers. The number and trend of articles on Islamic banks' performance published per year can be seen in Figure 1.

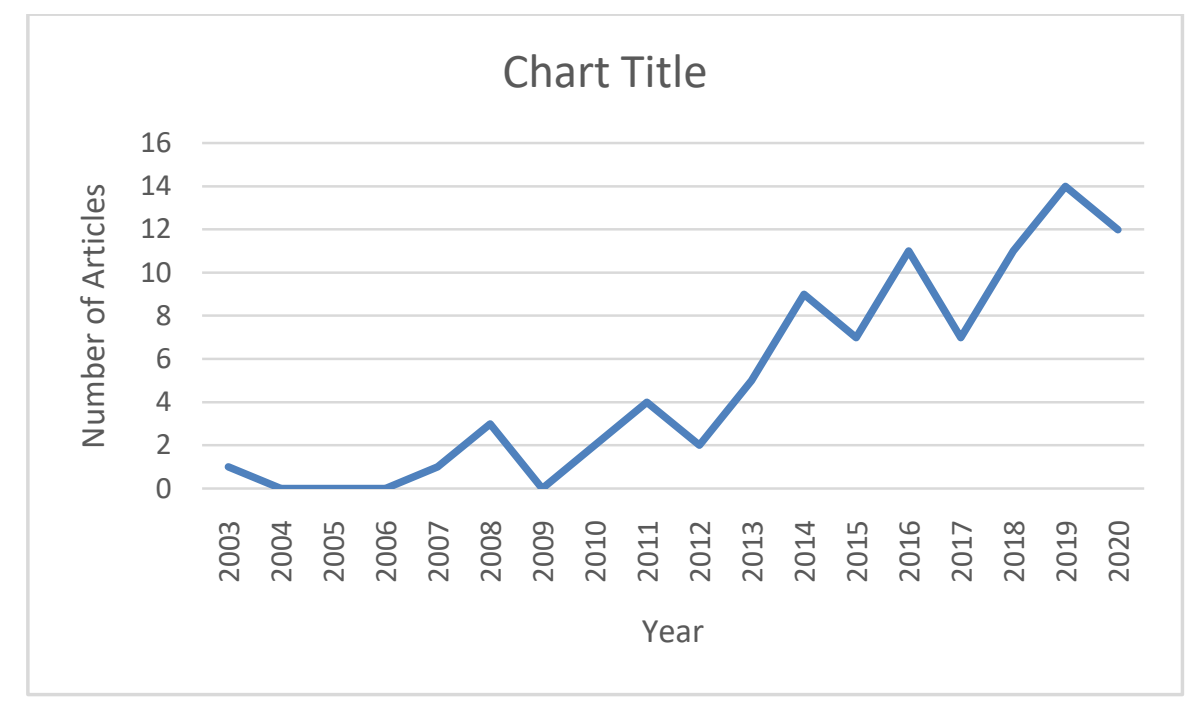

Figure 1. Islamic Banking Performance Research Trend per Year

The observation years were divided into three, with six-year periods, namely period I (20032008), period II (2009-2014), and period III (2015-2020). The specific issues raised in research on the measurement of Islamic banking performance varied widely. In several articles, researchers raised more than one specific issue to be discussed. The network of keyword co-occurrences analyzed using VOSviewer on Islamic banks' performance measurement can be seen in Figure 2 .

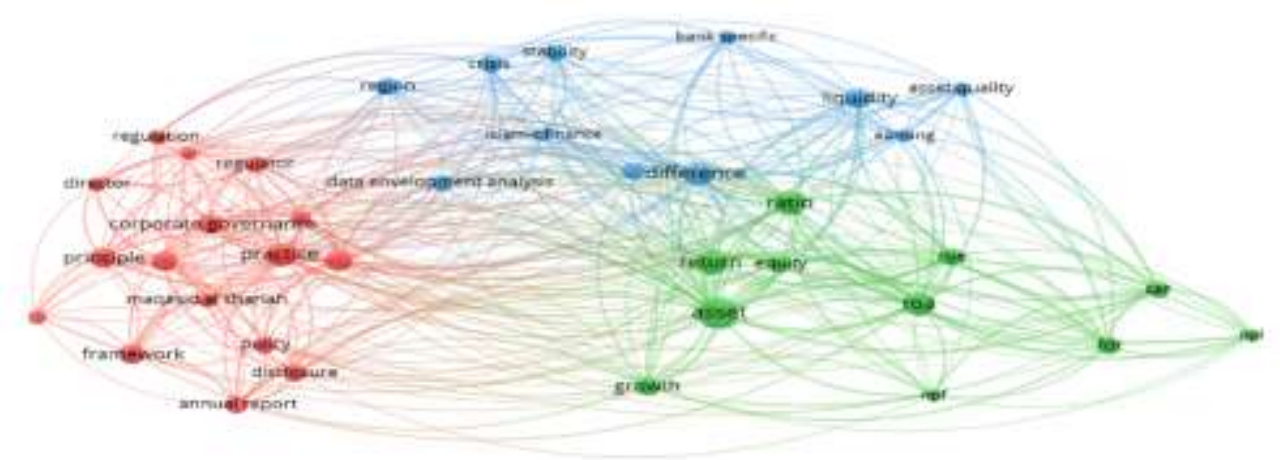

A. voswiewer

Figure 2. Keyword co-occurrence analysis on Islamic banks performance research 
The analysis with the VOSviewer application showed there were 3 clusters in red, blue, and green. In the red one, the words that appear the most were: "practice," "corporate governance," "framework," "principles," and "Shariah supervisory board." In the green cluster, the most popular words were "asset," "ratio," "return," "roa," and "equity," while in the blue one were "difference," "stability," "intellectual capital," "crisis," and "data envelope analysis." Based on the above keywords and content analysis, the authors divided specific issues into eight topics, namely: (1) Financial Performance on Islamic Banks: Comparative Studies, (2) Social Performances on Islamic Banks, (3) Efficiency, (4) Stability, (5) Good Corporate Governance (GCG)/Shariah Governance (SG), (6) Crisis and Regulation, (7) Intellectual Capital, and (8) Maqasid al-Shariah and other approaches.

Overall, the three research issues researched most over the past 20 years were the financial performance of Islamic banking (21\%), corporate governance (GCG) (21\%), and aspects of maqasid al-Shariah and other approaches (17\%). Significant increases in the three periods also occurred in these 3 issues. The financial performance of Islamic banking became the most popular topic throughout the study period (see Table 1).

Table 1. Paper Classification: Research Specific Issues

\begin{tabular}{|c|c|c|c|c|c|c|c|}
\hline \multirow{2}{*}{$\begin{array}{c}\text { Research Specific } \\
\text { Issues }\end{array}$} & \multicolumn{2}{|c|}{ 2003-2008 } & \multicolumn{2}{|c|}{ 2009-2014 } & \multicolumn{2}{|c|}{$2015-2020$} & \multirow{2}{*}{ Total } \\
\hline & Number & $\%$ & Number & $\%$ & Number & $\%$ & \\
\hline $\begin{array}{l}\text { IBs Financial } \\
\text { Performance }\end{array}$ & 2 & $67 \%$ & 6 & $29 \%$ & 11 & $18 \%$ & $19(21 \%)$ \\
\hline $\begin{array}{l}\text { IBs Social } \\
\text { Performance }\end{array}$ & 0 & $0 \%$ & 2 & $20 \%$ & 4 & $6 \%$ & $6(7 \%)$ \\
\hline Efficiency & 0 & $0 \%$ & 4 & $19 \%$ & 9 & $14 \%$ & $13(15 \%)$ \\
\hline Stability & 0 & $0 \%$ & 2 & $10 \%$ & 4 & $6 \%$ & $7(4 \%)$ \\
\hline GCG/SG & 0 & $0 \%$ & 3 & $14 \%$ & 16 & $24 \%$ & $19(21 \%)$ \\
\hline Crisis \& Regulation & 0 & $0 \%$ & 1 & $5 \%$ & 4 & $6 \%$ & $5(6 \%)$ \\
\hline Intellectual Capital & 0 & $0 \%$ & 0 & $0 \%$ & 6 & $9 \%$ & $6(7 \%)$ \\
\hline \multirow[t]{2}{*}{$\begin{array}{l}\text { Maqasid al-sharia } \\
\text { and other } \\
\text { approaches }\end{array}$} & 1 & $33 \%$ & 3 & $114 \%$ & 11 & $17 \%$ & $15(17 \%)$ \\
\hline & 3 & $100 \%$ & 21 & $100 \%$ & 66 & $100 \%$ & $89(100 \%)$ \\
\hline
\end{tabular}

IBs = Islamic Banks, GCG = Good Corporate Governance $\mathrm{SG}=$ Shariah Governance

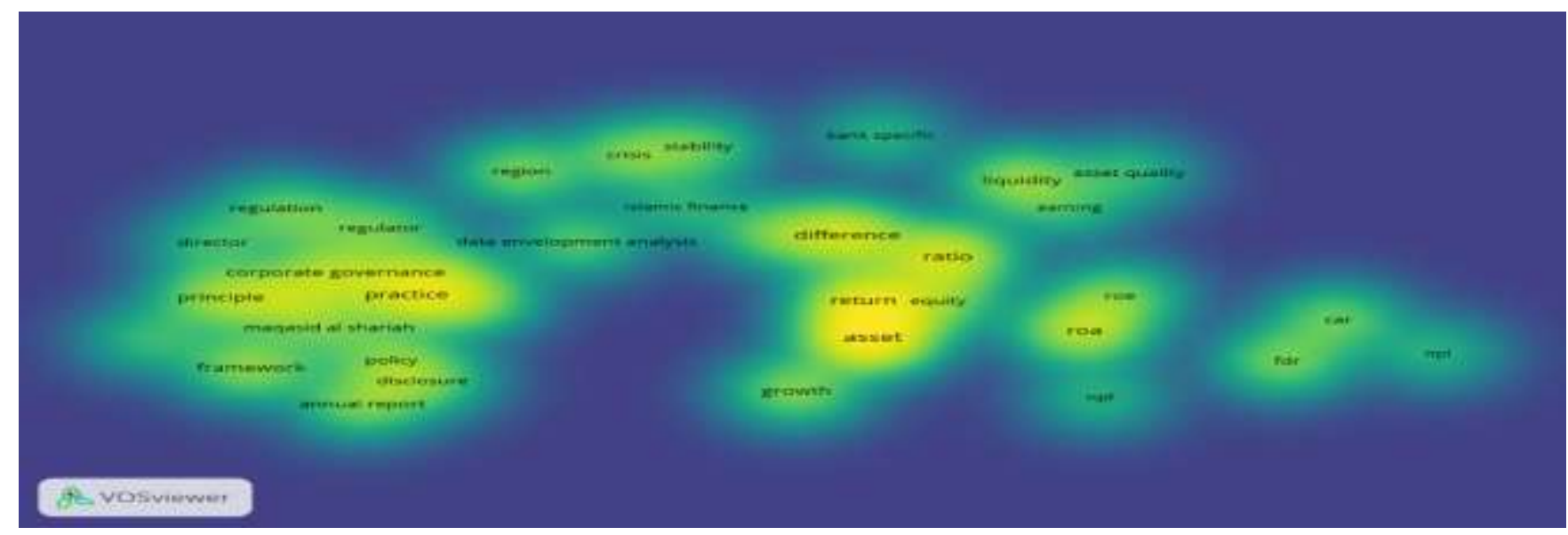

Figure 3. Analysis of research depth per keyword 
Based on the results of the VOSviewer (Figure 3), most of the research on the measurement of the Islamic banks' performance focused on financial performance (ratio, return, assets, difference, equity, ROA), Islamic banking practices, and governance. Meanwhile, bank-specific, maqasid alShariah, efficiency, and stability of Islamic banks were studied rarely. This indicates that the current scientists' attention focuses on Islamic banks' financial performance and governance. Measuring the performance of Islamic banks using maqasid al-Shariah, profitability, efficiency, and stability of Islamic banks is an important agenda for further research on the performance of Islamic banking.

\section{RESULTS \\ Islamic Banking Financial Performance: Comparative Study}

Comparative studies have always been an interesting issue for research on the performance of Islamic banking, both between Islamic banks (IBs) in one country, with conventional banks (CBs), foreign banks, and those across countries. Most of the studies use several financial ratios such as Return on Asset (ROA), Return on Equity (ROE), Return on Risk Asset (RORA) and Gross Profit Margin (GPM) to measure profitability, Capital Adequacy Ratio (CAR) to measure capital, Loan to Deposit Ratio (LDR) to measure liquidity, and the overall CAMELS ratio.

ROA is the best estimation in measuring the profitability of IBs. An important determinant of profitability is the fee received by IBs (Alhamditia \& Heykal, 2013; Islam, Alam, \& Hossain, 2014; Azad et al., 2019). Rosly and Bakar (2003) who examined the financial performance of Shariahschemed banks in Malaysia found that Islamic banks recorded high ROA achievements but with low efficiency due to the utilization of their overhead costs. In a comparative study with CBs, Toin (2014) assessed that the level of profitability of CBs is better than that of IBs. Ramlan and Adnan (2016) in Malaysia and Olson and Zoubi (2008) in the Gulf Cooperation Council (GCC) found that in IBs, profitability was influenced by ROA and ROE, while in CBs only influenced by ROE. They concluded that IBs was more profitable than BK. Research in OIC countries and the UK found that the profitability of IBs depends on the dynamics different from CBs (Yanikkaya et al., 2018). Sukmana and Suryaningtyas (2016) found that profit earned CBs will be allocated as liquid funds. Otherwise, IBs, when earns a profit, prefer to provide financing or improve fixed assets and technology rather than add liquid assets.

Comparative research on financial performance between IBs and CBs using the CAMELS ratio already conducted by Witjaksono and Yunistriani (2011) in Indonesia, Daly, and Frikha (2017) in Bahrain and found that the performance of IBs and CBs is homogeneous and similar; IBs only acts as a complement to CBs. Erol et al. (2014) in Turkey found that IBs performed better on profitability ratios and asset management but lagged on the sensitivity of market-risk criteria. However, in Malaysia, CBs performed better, notably on long-term capital and asset effects because they are more mature in management and operational systems (Hazman et al., 2018). Findings in Pakistan conducted by Rashid and Jabeen (2016) found that operating efficiency, reserves, and overhead are significant determinants of CBs' performance while operating efficiency, savings, and market concentration significantly affect the performance of IBs.

In another study, the capital adequacy ratio proxied by CAR in IBs and CBs in Indonesia is affected by macroeconomic factors, but this influence is preponderant for IBs (Rudianto \& Rahmiati, 2018). Tarek Al-Kayed et al. (2014) proved that the greater the capital, the better the IBs' performance.

In a comparative study of performance between IBs, CBs, and Islamic banking windows, Doumpos et al. (2017) proved statistically that IBs, Islamic banking windows, and CBs were not significantly different. CBs perform the best, compared to IBs and Islamic banking windows in Asia and GCC at the regional level, while IBs perform better in MENA and Senegal. The aforementioned occurred because of the influence of the unique characteristics of each country and their governments. The findings of Wasiuzzaman and Gunasegavan (2013) in Malaysia showed that the average return value of assets, bank size, and board size of CBs are higher than those of IBs. 
Meanwhile, operational efficiency, asset quality, liquidity, capital adequacy, and board independence were higher in IBs. In terms of capital and funding, mainly fully-fledged IBs adequately optimize several funding sources such as capital injections and increased tentative investment savings although Murabaha still dominates loans in IBs over profit-sharing due to its low risk and fixed income (Siswantoro, 2014).

\section{Islamic Banks' Social Performances}

A company's social performance is measured based on the Corporate Social Responsibility (CSR) report. Islamic ethics in IBs should pay attention to the social aspects of the environment in which they stand. Islamic banks have a vital role in improving social welfare, both for those who directly contribute to the companies' operations and those who do not directly contribute, such as society and nature (Triyuwono, 2011). CSR is also a part of sustainable practices in balancing economic growth with environmental protection and social equality that arises from a company's awareness that the community will assess its position in terms of environmental issues.

Sofyani et al. (2012) found that all IBs in Indonesia and Malaysia had not implemented 100\% ISR or achieved primely performance. Meanwhile, research by Arifin and Wardani (2016) showed that ICSR does not affect ROA performance. It is indicated that this occurs because the disclosure of the ICSR in Indonesia has not been extensive, especially about the information on profit-making activities of all company assets. Mallin et al. (2014) found that In general, IBs pay more attention to financial disclosure, as recommended by AAOIFI, but do not to the voluntary aspect, namely CSR. However, better financial performance encourages them to be involved in social activities, except in the dimension environment.

A study conducted by Jan et al. (2019) found the market is only interested in IBs' practices for economic sustainability rather than environmental and social sustainability. However, increasing sustainability practices will simultaneously add financial value to IBs' management, shareholders, and industrial markets as a whole. Meanwhile, Yudhiyati and Sholihin (2016) found political rights and personal freedom of a country, Muslim population, quality of Shariah governance, state economic conditions, and the size of Islamic banks are contextual variables that significantly influence social disclosure.

\section{Efficiency}

Efficiency is one indicator of banking performance that has received the attention of previous researchers. The theory of producers is based on the efficiency concept, which states that a company must achieve economic efficiency by producing maximum output from a certain amount of input (technical efficiency) and producing with the right combination at a certain price level (allocative efficiency) (Farrell, 1957).

In Indonesia, Pramuka (2011) found that an Islamic bank with a "full-fledged" scheme was more efficient than another one with an "Islamic window" scheme. Majdina et al. (2019) found a significant difference in efficiency in IBs and CBs: ROA had a significant positive impact on CBs' efficiency, while CAR had a significant positive effect on IBs'.

The relationship between efficiency and performance in Malaysia was investigated by Sufian (2007) by observing both domestic and foreign IBs. The results showed that domestic IBs were more efficient than foreign ones, and the efficiency was positive significantly correlated with profitability. Wanke et al. (2016) found that the efficiency of IBs in Malaysia was lower than that of IBs in US and European banks. IBs' inefficiency was related to the cost structure and the banks' origins, while efficiency was due to the work cultural traditions.

In Bangladesh, Miah and Sharmeen (2015) proved that CBs are more efficient in managing costs, compared to IBs. For cross-border IBs, Mostafa (2011) showed that several IBs had less than optimal efficiency performance, but had the potential to experience significant improvement, and 
Beck et al. (2013) found that IBs had less efficiency because they were less cost-effective but had a high intermediation risk.

In the Middle East (MENA), Mezzi (2018) found that IBs experienced increased cost efficiency, and Financial variables contributed to efficiency. Research conducted by Rosman et al . (2014) found that the technical efficiency of IBs in Asia was higher than that of IBs in the Middle East. IBs were able to sustain their operation through the financial crisis that occurred, but the study also showed that most of the IBs had an inefficient scale. The main determinants of efficiency in Islamic banks were profitability and capital.

\section{Stability}

The world financial crisis in 2007 claimed to have occurred due to the limitations of the traditional financial system. Interestingly, when all financial institutions experienced economic destabilization and paralysis, the Islamic financial system remained stable and secured its sustainability. The interest-free scheme is supposed fairer and able to maintain the stability of IBs with a higher shock absorption capacity than that of CBs (Fakhfekh et al., 2016; Ftiti et al., 2013; Trabelsi \& Trad, 2017).

Research on the stability and performance of IBs by Trad et al. (2017) in MENA countries and Pakistan found that bank and capital sizes were the main factors that led to improved financial performance and stability of IBs and their reduced credit risks. While IBs operating in the Gulf region were more profitable, more able to pay, and had reduced risks, compared to IBs in Southeast Asia. Bank capital had been proven to be the predominant indicator in maximizing profitability and stability and reducing credit risks. Researchers also found that the inflation rate in Southeast Asia increased the stability of IBs (Trabelsi \& Trad, 2017).

The stability of IBs in Indonesia is also influenced by bank capital (CAR) and inflation. Other factors that affect are the size and efficiency of IBs (Widarjono, 2020). Meanwhile, a cross-country study on the stability of IBs was conducted by Beck et al. (2013) found that IBs have better capital and higher asset quality to be more stable and less likely to become intermediaries during a crisis.

\section{Good Corporate Governance (CG) dan Shariah Governance (SG)}

Good corporate governance (GCG) is an essential aspect of Islamic banking. Weak GCG practice is alleged to be one of the causes of banks' barriers to recovery after the financial crisis some time ago (Siswanti, 2016). GCG is a system that functions to control the company and regulate the relationship between shareholders, the board of commissioners, the board of directors, and other stakeholders.

The IBs' performance is not only influenced by quantitative variables such as financial ratios but also by qualitative variables such as managerial qualifications as notable points in good IBs' governance (Ghayad, 2008). IBs' management still adheres to agency theory, strategic alignment theory, property theory, and trade-off theory, all of which are characteristics of CBs (Al-Malkawi \& Pillai, 2018). Meanwhile, increased transparency would prevent potential earnings manipulation and putting investors in a better position in managing the funds they invested (Lahrech et al., 2014).

The Islamic banking system becomes unique and different from conventional banks due to the existence of the Sharia Supervisory Board (SSB), which is responsible for the compliance of the IBs in operations and transactions with Islamic principles and rules. The SSB quality has a stronger impact on accounting disclosure in the decentralized Shariah governance model than in the centralized model. In the decentralized model, at a high level of SSB quality -even when performance decreases- IBs still adhere to the principle of full disclosure to inform stakeholders of the actual situation of the banks (Ajili \& Bouri, 2018). Ulama as SSB members acted more as advisors than supervisors, thus allowing managers to change their decisions. Also, because independent SSB members did not have complete information about the internal operations of the 
IBs, they needed to meet more frequently to coordinate. This increased the cost of holding meetings which affected the IB's income and performance (Khan \& Zahid, 2020; Alsartawi, 2019).

In Indonesia, Laela (2014) found a misfit between the educational strategy and its contingent variables led to a decrease in IBs' financial performance but did not affect IBs' social performance. This means that IBs needed to pay attention to the suitability between educational strategy with the competencies to improve organizational performance and achieving its sharia objectives. However, the effectiveness of SSB and the Board of Commissioners is proven to reduce the negative impact of misfit on IBs' performance (Wijayanti et al., 2020).

Mukhibad and Khafid (2018) and Siswanti (2016) found there was an indirect influence between the implementation of GCG on the performance of the IBs. A disclosure of GCG, SSB, temporary syirkah funds, and NPF affect the profitability of Islamic banks. Mukhibad et al. (2020) found that maqasid al-sharia is not a goal that must be achieved by IBs' management because a large amount of financing indicates that IBs' prefer fixed income and avoids the profit-sharing system.

Research by Dewindaru et al. (2019) and Farag et al. (2018) proved that SSB characteristics and the frequency of SSB meetings affect the financial performance and social performance of IBs. However, a study conducted by Kholid and Bachtiar (2015) obtained different results. The number of SSBs did not affect IB performance. Contrarily, the research of Bukair and Rahman (2015) and Al-Malkawi and Pillai (2018) found that the size and composition of the board of directors harm the performance of IBs.

Ali and Azmi (2016) found that IBs' boards of directors' members which are non-Muslims can run a business as great as that run by the Muslim members. They concluded that religious orientation does not affect the performance of IBs. Aslam and Haron (2020) found a direct impact of GCG on the performance of IBs, and intellectual capital (IC) mediates the CG mechanism on the performance.

Apart from SSB, the board of directors, management, and the ownership structure are aspects that influence IBs' governance. Research conducted by Zouari and Taktak (2014) found that IBs' with foreign ownership structures did not perform better than how those with domestic ownership structures did. The findings of Mateev and Bachvarov(2020) showed that ownership structures play a limited role in the performance of IBs, while foreign ownership structures have a significant positive effect on IBs.

\section{Crisis and Regulation}

The world financial crisis in 2007 occurred due to the inefficiency of the banking framework and weak regulations and supervision in the provision of credit and issuance of financial instruments by banks (Alam et al., 2019). Interestingly, the current crisis did not have a severe impact on Islamic banking because IBs' operations were built upon Islamic law, which prioritizes real transactions between two parties, ensures risk-sharing in contracts, and prohibits usury. No derivative of interest transactions and distribution of funding led to projects with added economic values (Alam et al., 2019; Khan, 2010).

Differences in IBs and CBs business models have caused different effects of their respective liquidity on the country's financial stability. IBs create liquidity by using assets to channel funding, while CBs do through securities and off-balance sheet loan commitments. As a result, when the crisis occurred, IBs could withstand it because their operations were based on real projects. The creation of liquidity in CBs reduces national financial stability in high-income countries and does not affect low-income countries. On the other hand, the IBs liquidity creation does not affect highincome countries but significantly increases stability in low-income countries (Berger et al., 2019). The improvement of Conventional banking technology had caused the global financial crisis. IBs needs a long time to equalize the profitability of CBs after the global financial crisis because of the CBs' profit smoothing management practices used by IBs (Alexakis et al., 2019). 
To reduce the impact of the crisis on the stability of the banking system, the government made several regulations, which would assuredly affect the performance of Islamic banks. The research found that the variable regulations positively and significantly influenced IBs' performance in the South and Southeast Asia (SSA) region but did not in the GCC region because, in countries in the SSA region that used Islamic law as its fundamentals, IBs did not need special regulations, and needed them in countries that were not based on Shariah law. Separate laws for IBs would help to improve their performance (Alam et al., 2019). The regulation size had an influential effect on driving the profitability of IBs (Mateev \& Bachvarov, 2020).

\section{Intellectual Capital}

Intellectual capital (IC) is a structure that cannot be seen with naked eyes (intangible asset) but is an important asset in building an organization. IC is usually measured by Value Added Intellectual Coefficient (VAIC), which is an added value obtained by the company because it has employees who have the skills according to the needs and the efficiency of the organizational structure that encourages increased company performance.

In Indonesia, Lestari et al. (2016) found that IC affects a company's financial performance and that IC of the previous period affected IBs' financial performance in the current period. Rahajeng and Hasibuan (2020) obtained different results: IC does not significantly affect the financial performance of IBs, but partially human capital and structural capital have a significant effect on profitability. Anggani and Widagdo (2019) found that GCG has significant implications for IC performance, while family ownership and foreign ownership do not.

Reports by Nawaz and Haniffa (2017) from 18 countries in the world, Ousama et al. (2019) from Bahrain, Qatar, South Asia, and the UAE, and Buallay (2019) from GCC found that there was a positive and significant influence between IC and IBs' financial performance.

\section{Maqasid Shariah and another approach}

One of the main objectives of establishing IBs within the framework of Shariah objectives is to create and distribute wealth fairly to improve social welfare, benefit all people, and not only focus on fulfilling economic aspects for stakeholders (Hassan \& Aliyu, 2018; Dusuki, 2008). The objectives of Shariah require a balance between the achievement of socio-economic goals and upholding justice for the accomplishment of maslahah by fulfilling the five elements of maqasid alsharia, namely; safeguarding religion (deen), safeguarding human self (nafs), safeguarding intellect (aql), safeguarding posterity ( $n a s l$ ) and safeguarding wealth ( $m a l$ ) simultaneously. The five elements should be a performance measurement framework by transforming them directly into aspects of management and governance (Ishak \& Asni, 2020; Soediro \& Meutia, 2018).

Nowadays, the vision, mission, and objectives of Islamic banks are still profit-oriented rather than social-oriented (Mohammad \& Shahwan, 2013). Besides, traditional performance measurement systems such as CAMELS are built based on property theory and agency theory emphasizing financial aspects more than non-financial regards such as social welfare and the environment. To ensure that their activities are by Shariah objectives, IBs require a performance measurement tool that is certainly different from that of CBs. The IBs' performance measurement model should ideally integrate the dimensions: finance, brotherhood and justice, and social welfare (Adib \& Khalid, 2010; Azmy, 2015).

Triyuwono (2011) tried to formulate performance measurements based on Shariah Enterprise Theory, which consists of Amanah management, Non-economic Wealth, Give out, Earning, capital and assets, Liquidity and Sensitivity to market, and Socio-economic wealth (ANGELS), to be tested by Oktaviansyah et al. (2018), resulting in that IBs' health rating was categorized as good. Several inputs were given, such as in terms of the indicators of trust management which were still contrary to what was practiced in IBs. 
The IBs performance measurement formulations based on maqasid al-sharia have been done by several scientists. Bedoui \& Mansour (2015) compiled performance measurements by using a Pentagon-shaped approach based on maqasid Al-Ghazali, who was qualified by Chapra, then transformed them into performance ratios. If the company's orientation is only in the wealth sector, then the performance calculation results will be zero and the performance will be considered as low in the perspective of maqasid al-Shariah.

Tarique et al. (2020) developed performance measurement based on Maqasid Ibnu Ashur, called the Maqasid based Performance Evaluation Model (MPEM). Mohammed \& Taib (2015) produced Performance Measures based on Maqasid al-Shariah (PMMS) consisting of education, justice, and maslahah. PMMS was tested and compared with CBs performance measurements (ROA, NII, and LIQ) in 24 Islamic banks and their counterparts. As a result, the performance of the IBs measured using PMMS was better than the CBs. In contrast, with traditional performance ratios, IBs underperform, compared to CBs. The same results were obtained by Sutrisno (2017) in Indonesia and Julia and Kassim (2019) in Bangladesh. Hudaefi and Noordin (2019) developed the Integrated Maqasid al-Shariah index for Measuring the Performance of Islamic banks (IMSPM) and tested it on $11 \mathrm{IBs}$ in the world. They found that the highest performance achieved by the sample IBs was on self-goals (nafs). In Southeast Asian countries, Mutia and Musfirah (2017) found no significant difference in the performance of all IBs as measured by Maqasid al-Shariah Index.

\section{DISCUSSION}

We found that previous researchers measured IBs performance with financial ratios such as ROA, ROE, CAR, Equity, and Asset. Most of the literature of comparative investigation proved that CBs performed better than how IBs did, and some claimed that IBs only act as a complement to CBs with practices similar to CBs. However, what was unique is that in several countries that use Islamic law as its fundamentals, IBs had an optimal performance. Also, the high performance of IBs was influenced by the capital size. These provided evidence that the operation of IBs is different from that of $\mathrm{CBs}$, thus requiring separate regulations according to the characteristics, such as the capitalrelated requirements that must be met by the IBs.

Most of IBs have not fully implemented CSR. Empirical studies from various studies proved this happened because IBs focused more on improving financial performance while social and environmental disclosure activities in CSR would not affect improving financial performance. However, a recent study on corporate social responsibility disclosure found that CSR activities have a long-term positive effect on Islamic banking performance. It is necessary to develop policies related to this matter because CSR is a real reflection of the sharia objectives adopted by IBs in improving optimal social and environmental welfare.

Although most of the research in the early decades revealed that IBs were inefficient in cost, recent studies proved that they performed better and efficiently in times of crisis. Other research showed that high capitalization and size development make IBs more resilient to crises and stabler, indicating that regulation and supervision of capital adequacy and stable funding ratios will increase the soundness and financial stability of Islamic banking.

Empirical research that explored IBs in the attainment of maqasid al-Shariah was very limited, but most of them concluded that the accomplishment of maqasid in IBs was still inadequate. It seems that profit orientation is still the operational trend of IBs. Maqasid al-Shariah is not the primary goal that must be achieved by IBs' management, seen in several IBs choosing Murabaha financing transactions that generate fixed income other than adopting the profit-sharing system (Mukhibad et al., 2020). Besides, the existing maqasid al-Shariah-based performance measurement system is still inadequate as a tool in predicting future IBs activities because most of the financial and non-financial information needed to build a maqasid framework is not yet available in the IBs' annual reports. For this reason, it is necessary to formulate Islamic bank reporting indicators that accommodate the information needed for measuring the performance of Maqasid al-Shariah. 


\section{CONCLUSIONS}

Measuring the performance of Islamic banks should be based on three aspects: financial, social, and its contribution to financial system stability. We found that in the last two decades, researchers focused on Islamic banks' financial performance. Social performance in the form of CSR and the relationship between IBS performance on financial system stability are only discussed in a few papers. However, in the last six years, researchers tended to focus on GCG and maqasid alShariah, meaning that there was concern in the application of Shariah banking governance and performance measurement systems that were deemed not in accordance with the characteristics of Shariah banks and Shariah objectives.

\section{REFERENCES}

Adib, N., \& Khalid, S. N. A. (2010). Performance Measurement System in Islamic Bank: Some Issues and Considerations. Jurnal Akuntansi Multiparadigma. https://doi.org/10.18202/jamal.2010.12.7104

Ajili, H., \& Bouri, A. (2018). Assessing the moderating effect of Shariah Board on the relationship between financial performance and accounting disclosure. Managerial Finance, 44(5), 570 589. https://doi.org/10.1108/MF-05-2017-0192

Akber, S. M., \& Dey, A. (2020). Evaluation of the Financial Performance between Traditional Private Commercial Banks and Islamic Banks in Bangladesh. International Journal of Islamic Banking and Finance Research, 4(2), 1-10. https://doi.org/10.46281/ijibfr.v4i2.640

Alam, N., Binti Zainuddin, S. S., \& Rizvi, S. A. R. (2019). Ramifications of varying banking regulations on performance of Islamic Banks. Borsa Istanbul Review, 19(1), 49-64. https://doi.org/10.1016/j.bir.2018.05.005

Alexakis, C., Izzeldin, M., Johnes, J., \& Pappas, V. (2019). Performance and productivity in Islamic and conventional banks: Evidence from the global financial crisis. Economic Modelling, 79, 1-14. https://doi.org/10.1016/j.econmod.2018.09.030

Alhamditia, E. R., \& Heykal, M. (2013). Analysis of Estimates and Factors Affecting the Profitability Level of Islamic Commercial Banks in Indonesia (Case Study of PT Bank Syariah Mandiri Period 2008-2011). Binus Business Review, 4(1), 186. https://doi.org/10.21512/bbr.v4i1.1046

Ali, M., \& Azmi, W. (2016). Religion in the boardroom and its impact on Islamic banks' performance. Review of Financial Economics, 31, 83-88. https://doi.org/10.1016/j.rfe.2016.08.001

Al-Malkawi, H.-A. N., \& Pillai, R. (2018). Analyzing financial performance by integrating conventional governance mechanisms into the GCC Islamic banking framework. Managerial Finance, 44(5), 604-623. https://doi.org/10.1108/MF-05-2017-0200

Anggani, Y. T., \& Widagdo, A. K. (2019). Intellectual capital performance of Sharia banks: Evidence from Indonesia. Jurnal Keuangan Dan Perbankan, 23(4), 579-594. https://doi.org/10.26905/jkdp.v23i4.3563 
Arifin, J., \& Wardani, E. A. (2016). Islamic corporat social responsibility disclosure, reputasi, dan kinerja keuangan: Studi pada bank syariah di Indonesia. Jurnal Akuntansi \& Auditing Indonesia, 20(1), 38-46. https://doi.org/10.20885/jaai.vol20.iss1.art4

Aslam, E., \& Haron, R. (2020). Corporate governance and banking performance: The mediating role of intellectual capital among OIC countries. Corporate Governance, 26. https://doi.org/10.1108/CG-08-2020-0312

Azad, A. S. M. S., Azmat, S., \& Hayat, A. (2019). What determines the profitability of Islamic banks: Lending or fee? International Review of Economics \& Finance, S1059056018306877. https://doi.org/10.1016/j.iref.2019.05.015

Azmy, A. (2015). Developing Strategic Human Resource Management to Support Organizational Competitiveness: A Performance Management Perspective in Islamic Banks. Binus Business Review, 6(1), 78. https://doi.org/10.21512/bbr.v6i1.989

Beck, T., Demirgüç-Kunt, A., \& Merrouche, O. (2013). Islamic vs. conventional banking: Business model, efficiency and stability. Journal of Banking \& Finance, 37(2), 433-447. https://doi.org/10.1016/j.jbankfin.2012.09.016

Bedoui, H. E., \& Mansour, W. (2015). Performance and Maqasid al-Shari'ah's Pentagon-Shaped Ethical Measurement. Science and Engineering Ethics, 21(3), 555-576. https://doi.org/10.1007/s11948-014-9561-9

Ben Slama Zouari, S., \& Boulila Taktak, N. (2014). Ownership structure and financial performance in Islamic banks: Does bank ownership matter? International Journal of Islamic and Middle Eastern Finance and Management, 7(2), 146-160. https://doi.org/10.1108/IMEFM-01-20130002

Berger, A. N., Boubakri, N., Guedhami, O., \& Li, X. (2019). Liquidity creation performance and financial stability consequences of Islamic banking: Evidence from a multinational study. Journal of Financial Stability, 44, 100692. https://doi.org/10.1016/j.jfs.2019.100692

Buallay, A. (2019). Intellectual capital and performance of Islamic and conventional banking: Empirical evidence from Gulf Cooperative Council countries. Journal of Management Development, 38(7), 518-537. https://doi.org/10.1108/JMD-01-2019-0020

Bukair, A. A., \& Rahman, A. A. (2015). Bank performance and board of directors attributes by Islamic banks. International Journal of Islamic and Middle Eastern Finance and Management, 8(3), 291-309. https://doi.org/10.1108/IMEFM-10-2013-0111

Daly, S., \& Frikha, M. (2017). Determinants of bank Performance: Comparative Study Between Conventional and Islamic Banking in Bahrain. Journal of the Knowledge Economy, 8(2), 471-488. https://doi.org/10.1007/s13132-015-0261-8

Dewindaru, D., Saleh, S., \& Muhammad, R. (2019). Characteristics of the Supervisory Board as a Determinant of the Social Performance of a Sharia Bank.Jurnal Akuntansi Multiparadigma, 10(3). https://doi.org/10.21776/ub.jamal.2019.10.3.27 
Doumpos, M., Hasan, I., \& Pasiouras, F. (2017). Bank overall financial strength: Islamic versus conventional banks. Economic Modelling, 64, 513-523. https://doi.org/10.1016/j.econmod.2017.03.026

Dusuki, A. W. (2008). Understanding the objectives of Islamic banking: A survey of stakeholders' perspectives. International Journal of Islamic and Middle Eastern Finance and Management, 1(2), 132-148. https://doi.org/10.1108/17538390810880982

Erol, C., F. Baklaci, H., Aydoğan, B., \& Tunç, G. (2014). Performance comparison of Islamic (participation) banks and commercial banks in Turkish banking sector. EuroMed Journal of Business, 9(2), 114-128. https://doi.org/10.1108/EMJB-05-2013-0024

Fakhfekh, M., Hachicha, N., Jawadi, F., Selmi, N., \& Idi Cheffou, A. (2016). Measuring volatility persistence for conventional and Islamic banks: An FI-EGARCH approach. Emerging Markets Review, 27(C), 84-99. https://doi.org/DOI: 10.1016/j.ememar.2016.03.004

Farag, H., Mallin, C., \& Ow-Yong, K. (2018). Corporate governance in Islamic banks: New insights for dual board structure and agency relationships. Journal of International Financial Markets, Institutions and Money, 54, 59-77. https://doi.org/10.1016/j.intfin.2017.08.002

Farrell, M. J. (1957). The Measurement of Productive Efficiency. Journal of the Royal Statistical Society: Series A (General), 120(3), 253-281. https://doi.org/10.2307/2343100

Ftiti, Z., Nafti, O., \& Sreiri, S. (2013). Efficiency of Islamic Banks During Subprime Crisis: Evidence Of GCC Countries. Journal of Applied Business Research (JABR), 29(1), 285-304. https://doi.org/10.19030/jabr.v29i1.7615

Ghayad, R. (2008). Corporate governance and the global performance of Islamic banks. Humanomics, 24(3), 207-216. https://doi.org/10.1108/08288660810899368

Hassan, M. K., \& Aliyu, S. (2018). A contemporary survey of islamic banking literature. Journal of Financial Stability, 34, 12-43. https://doi.org/10.1016/j.jfs.2017.11.006

Hazman, S., Nasir, N. M., Zairihan, A. H., \& Syahmi, S. A. (2018). Financial Performance Evaluation of Islamic Banking System: A Comparative Study among Malaysia's Banks. Jurnal Ekonomi Malaysia, 12. http://dx.doi.org/10.17576/JEM-2018-5202-11

Hudaefi, F. A., \& Noordin, K. (2019). Harmonizing and constructing an integrated maqāșid alSharī $a h$ index for measuring the performance of Islamic banks. ISRA International Journal of Islamic Finance, 11(2), 282-302. https://doi.org/10.1108/IJIF-01-2018-0003

Ishak, M. S. I., \& Asni, F. (2020). The role of maqasid al-Shari 'ah in applying fiqh muamalat into modern Islamic banking in Malaysia. Journal of Islamic Accounting and Business Research, 11(9), 2137-2154. https://doi.org/10.1108/JIABR-12-2019-0224

Islam, K. M. A., Alam, I., \& Hossain, S. A. (2014). Examination of profitability between Islamic banks and conventional banks in Bangladesh: A comparative study. Research in Business and Management, 1(1), 78-89. 
Jan, A., Marimuthu, M., \& @ Mat Isa, M. P. bin M. (2019). The nexus of sustainability practices and financial performance: From the perspective of Islamic banking. Journal of Cleaner Production, 228, 703-717. https://doi.org/10.1016/j.jclepro.2019.04.208

Julia, T., \& Kassim, S. (2019). Exploring green banking performance of Islamic banks vs conventional banks in Bangladesh based on Maqasid Shariah framework. Journal of Islamic Marketing, 11(3), 729-744. https://doi.org/10.1108/JIMA-10-2017-0105

Keffala, M. R. (2020). "How using derivative instruments and purposes affects performance of Islamic banks? Evidence from CAMELS approach.” Global Finance Journal, 100520. https://doi.org/10.1016/j.gfj.2020.100520

Khan, F. (2010). How 'Islamic' is Islamic Banking? Journal of Economic Behavior \& Organization, 76(3), 805-820. https://doi.org/10.1016/j.jebo.2010.09.015

Khan, I., \& Zahid, S. N. (2020). The impact of Shari'ah and corporate governance on Islamic banks performance: Evidence from Asia. International Journal of Islamic and Middle Eastern Finance and Management, ahead-of-print(ahead-of-print). https://doi.org/10.1108/IMEFM01-2019-0003

Kholid, M. N., \& Bachtiar, A. (2015). Good corporate governance dan kinerja maqasid syariah bank syariah di Indonesia. Jurnal Akuntansi \& Auditing Indonesia, 19(2), 126-136. https://doi.org/10.20885/jaai.vol19.iss2.art4

Laela, S. F. (2014). Dynamic Strategic-Fit dan Kinerja: Studi pada Perbankan Syariah. Jurnal Akuntansi dan Keuangan Indonesia, 11(1), 20-39. https://doi.org/10.21002/jaki.2014.02

Lahrech, N., Lahrech, A., \& Boulaksil, Y. (2014). Transparency and performance in Islamic banking: Implications on profit distribution. International Journal of Islamic and Middle Eastern Finance and Management, 7(1), 61-88. https://doi.org/10.1108/IMEFM-06-20120047

Lestari, S. D., Paramu, H., \& Sukarno, H. (2016). The Influence of Intellectual Capital on the Financial Performance of Syari'ah Banking in Indonesia.EKUITAS (Jurnal Ekonomi dan Keuangan), 20(3), 346-366. https://doi.org/10.24034/j25485024.y2016.v20.i3.64

Maharani, S. N., \& Rahmawati, S. A. (2020). Reconstruction of Islamic Banking Performance Measurement Models: A Critical Thought. Utopía y Praxis Latinoamericana, 25(1), 155165. https://doi.org/10.5281/zenodo.3774599

Majdina, N., Munandar, J. M., \& Effendi, J. (2019). The determinant factors of efficiency on Islamic banking and conventional banking in Indonesia. Jurnal Keuangan Dan Perbankan, 23(3). https://doi.org/10.26905/jkdp.v23i3.3157

Mallin, C., Farag, H., \& Ow-Yong, K. (2014). Corporate social responsibility and financial performance in Islamic banks. Journal of Economic Behavior \& Organization, 103, S21S38. https://doi.org/10.1016/j.jebo.2014.03.001 
Mateev, M., \& Bachvarov, P. (2020). Regulation, ownership and bank performance in the MENA region: Evidence for Islamic and conventional banks. Emerging Markets Review, 100789. https://doi.org/10.1016/j.ememar.2020.100789

Mezzi, N. (2018). Efficiency of Islamic banks and role of governance: Empirical evidence. Managerial Finance, 44(5), 590-603. https://doi.org/10.1108/MF-05-2017-0171

Miah, Md. D., \& Sharmeen, K. (2015). Relationship between capital, risk and efficiency: A comparative study between Islamic and conventional banks of Bangladesh. International Journal of Islamic and Middle Eastern Finance and Management, 8(2), 203-221. https://doi.org/10.1108/IMEFM-03-2014-0027

Mohammad, M. O., \& Shahwan, S. (2013). The Objective of Islamic Economic and Islamic Banking in Light of Maqasid Al-Shariah: A Critical Review. Middle East Journal of Scientific Research, 10. https://doi.org/10.5829/idosi.mejsr.2013.13.1885

Mohammed, M. O., \& Taib, F. M. (2015). Developing Islamic Banking Performance Measures Based on Maqasid Al-Shari'ah Framework: Cases of 24 Selected Banks. Journal of Islamic Monetary Economics and Finance, 1(1), 55-77. https://doi.org/10.21098/jimf.v1i1.483

Mostafa, M. M. (2011). Modeling Islamic banks' efficiency: A non-parametric frontier approach. International Journal of Islamic and Middle Eastern Finance and Management, 4(1), 7-29. https://doi.org/10.1108/17538391111122186

Mukhibad, H., \& Khafid, M. (2018). Financial Performance Determinant of Islamic Banking in Indonesia. Jurnal Keuangan Dan Perbankan, 22(3). https://doi.org/10.26905/jkdp.v22i3.2061

Mukhibad, H., Rochmatullah, M. R., Warsina, W., Rahmawati, R., \& Setiawan, D. (2020). Islamic corporate governance and performance based on maqasid sharia index-study in Indonesia. Jurnal Siasat Bisnis, 24(2), 114-126. https://doi.org/10.20885/jsb.vol24.iss2.art2

Mukhlis, I. (2012). Bank Financial Performance and Macroeconomic Stability Towards The Profitability Of Sharia Banks In Indonesia. Jurnal Keuangan Dan Perbankan, 16(2), Article 2. https://doi.org/10.26905/jkdp.v16i2.1068

Musleh Alsartawi, A. (2019). Performance of Islamic banks: Do the frequency of Sharīah supervisory board meetings and independence matter? ISRA International Journal of Islamic Finance, 11(2), 303-321. https://doi.org/10.1108/IJIF-05-2018-0054

Mutia, E., \& Musfirah, N. (2017). The Maqashid Shariah Index Approach as a Performance Measurement of Islamic Banking in Southeast Asia. Jurnal Akuntansi dan Keuangan Indonesia, 14(2), 181-201. https://doi.org/10.21002/jaki.2017.10

Nawaz, T., \& Haniffa, R. (2017). Determinants of financial performance of Islamic banks: An intellectual capital perspective. Journal of Islamic Accounting and Business Research, 8(2), 130-142. https://doi.org/10.1108/JIABR-06-2016-0071 
Neely, A. (1999). the Performance measurement revolution: Why now and what next? International Journal of Operations \& Production Management, 19(2), 205-228. https://doi.org/10.1108/01443579910247437

Nurindrasari, D., Triyuwono, I., \& Mulawarman, A. D. (2018). The Concept of Performance Measurement Based on Islamic Welfare. Jurnal Akuntansi Multiparadigma, 9(3). https://doi.org/10.18202/jamal.2018.04.9024

Oktaviansyah, H. T., Roziq, A., \& Sulistiyo, A. B. (2018). ANGELS Rating System for Islamic Banking Industry in Indonesia. Jurnal Keuangan Dan Perbankan, 22(1). https://doi.org/10.26905/jkdp.v22i1.1563

Olson, D., \& Zoubi, T. A. (2008). Using accounting ratios to distinguish between Islamic and conventional banks in the GCC region. The International Journal of Accounting, 43(1), 4565. https://doi.org/10.1016/j.intacc.2008.01.003

Ousama, A. A., Hammami, H., \& Abdulkarim, M. (2019). The association between intellectual capital and financial performance in the Islamic banking industry: An analysis of the GCC banks. International Journal of Islamic and Middle Eastern Finance and Management, 13(1), 75-93. https://doi.org/10.1108/IMEFM-05-2016-0073

Pramuka, B. A. (2011). Assesing Profit Efficiency of Islamic Banks in Indonesia: An Intermediation Approach. Journal of Economics, Business, and Accountancy | Ventura, 14(1). https://doi.org/10.14414/jebav.v14i1.21

Rahajeng, D. K., \& Hasibuan, N. Z. (2020). Does Intellectual Capital Matter? A Case Study of Indonesia Sharia Banks. The Indonesian Journal of Accounting Research, 23(02). https://doi.org/10.33312/ijar.475

Ramlan, H., \& Adnan, M. S. (2016). The Profitability of Islamic and Conventional Bank: Case Study in Malaysia. Procedia Economics and Finance, 35, 359-367. https://doi.org/10.1016/S2212-5671(16)00044-7

Rashid, A., \& Jabeen, S. (2016). Analyzing performance determinants: Conventional versus Islamic Banks in Pakistan. Borsa Istanbul Review, 16(2), 92-107. https://doi.org/10.1016/j.bir.2016.03.002

Rosly, S. A., \& Bakar, M. A. A. (2003). Performance of Islamic and mainstream banks in Malaysia. International Journal of Social Economics, 30(12), 1249-1265. https://doi.org/10.1108/03068290310500652

Rosman, R., Wahab, N. A., \& Zainol, Z. (2014). Efficiency of Islamic banks during the financial crisis: An analysis of Middle Eastern and Asian countries. Pacific-Basin Finance Journal, 28, 76-90. https://doi.org/10.1016/j.pacfin.2013.11.001

Rudianto, D., \& Rahmiati, T. S. (2018). Performance Comparison Berween Islamic Banks and Conventional Banks in Indonesia. EKUITAS (Jurnal Ekonomi Dan Keuangan), 18(1). https://doi.org/10.24034/j25485024.y2014.v18.i1.102 
Siswanti, I. (2016). Implementasi Good Corporate Governance pada Kinerja Bank Syariah. Jurnal Akuntansi Multiparadigma, 7(2), 156-323. https://doi.org/10.18202/jamal.2016.08.7023

Siswantoro, D. (2014). Analysis of Islamic Bank's Performance and Strategy After Spin-off as Islamic Full-fledged Scheme in Indonesia. Procedia - Social and Behavioral Sciences, 164, 41-48. https://doi.org/10.1016/j.sbspro.2014.11.048

Soediro, A., \& Meutia, I. (2018). Maqasid Syariah as a Performance Framework for Islamic Financial Institutions. Jurnal Akuntansi Multiparadigma, 9(1). https://doi.org/10.18202/jamal.2018.04.9005

Sofyani, H., Ulum, I., \& Syam, D. (2012). Islamic Social Reporting Incex sebagai Model Pengukuran Kinerja Sosial Perbankan Syariah (Studi Komparasi Indonesia dan Malaysia). Jurnal Dinamika Akuntansi, 4(1), 11. https://doi.org/10.15294/jda.v4i1.1958

Sufian, F. (2007). The efficiency of Islamic banking industry in Malaysia: Foreign vs domestic banks. Humanomics, 23(3), 174-192. https://doi.org/10.1108/08288660710779399

Sukmana, R., \& Suryaningtyas, S. (2016). Determinants of Liquidity Risk in Indonesian Islamic and Conventional Banks: A Panel Regression. Al-Iqtishad: Journal of Islamic Economics, 8(2), 187-200. https://doi.org/10.15408/aiq.v8i2.2871

Sutrisno, S. (2017). Pengukuran Kesehatan Bank Syariah dengan Sharia Complience and Performance. Jurnal Keuangan dan Perbankan, 21(1), 133-143. https://doi.org/10.26905/jkdp.v21i1.1234

Tarek Al-Kayed, L., Raihan Syed Mohd Zain, S., \& Duasa, J. (2014). The relationship between capital structure and performance of Islamic banks. Journal of Islamic Accounting and Business Research, 5(2), 158-181. https://doi.org/10.1108/JIABR-04-2012-0024

Tarique, K. M., Islam, R., \& Mohammed, M. O. (2020). Developing and validating the components of Maqasid al-Shari'ah-based performance measurement model for Islamic banks. International Journal of Islamic and Middle Eastern Finance and Management, ahead-of$\operatorname{print}($ ahead-of-print). https://doi.org/10.1108/IMEFM-12-2018-0432

Toin, D. R. Y. (2014). Banking performance analysis (comparative study between Islamic and conventional banking). Jurnal Siasat Bisnis, 18(2), 202-209. https://doi.org/10.20885/jsb.vol18.iss2.art6

Trabelsi, M. A., \& Trad, N. (2017). Profitability and risk in interest-free banking industries: A dynamic panel data analysis. International Journal of Islamic and Middle Eastern Finance and Management, 10(4), 454-469. https://doi.org/10.1108/IMEFM-05-2016-0070

Trad, N., Trabelsi, M. A., \& Goux, J. F. (2017). Risk and profitability of Islamic banks: A religious deception or an alternative solution? European Research on Management and Business Economics, 23(1), 40-45. https://doi.org/10.1016/j.iedeen.2016.09.001

Triyuwono, I. (2011). ANGELS: A Syari'ah Bank's Health Rating System.Jurnal Akuntansi Multiparadigma, 2(1), 1-21. https://doi.org/10.18202/jamal.2011.04.7107 
Wanke, P., Azad, M. D. A. K., \& Barros, C. P. (2016). Predicting efficiency in Malaysian Islamic banks: A two-stage TOPSIS and neural networks approach. Research in International Business and Finance, 36, 485-498. https://doi.org/10.1016/j.ribaf.2015.10.002

Wasiuzzaman, S., \& Gunasegavan, U. N. (2013). Comparative study of the performance of Islamic and conventional banks: The case of Malaysia. Humanomics, 29(1), 43-60. https://doi.org/10.1108/08288661311299312

Widarjono, A. (2020). Stability of Islamic banks in Indonesia: Autoregressive Distributed Lag Approach. Jurnal Keuangan Dan Perbankan, 24(1), 40-52. https://doi.org/10.26905/jkdp.v24i1.3932

Wijayanti, R., Diyanty, V., \& Laela, S. F. (2020). Education strategy misfit, board effectiveness and Indonesian Islamic bank performance. Journal of Islamic Accounting and Business Research, 11(3), 929-944. https://doi.org/10.1108/JIABR-04-2017-0052

Witjaksono, A., \& Yunistriani, A. (2011). A Comparative Analysis of Financial Performance Between Islamic Banks and Conventional Banks Based On The CAMEL Method. Binus Business Review, 2(1), 485. https://doi.org/10.21512/bbr.v2i1.1155

Yanikkaya, H., Gumus, N., \& Pabuccu, Y. U. (2018). How profitability differs between conventional and Islamic banks: A dynamic panel data approach. Pacific-Basin Finance Journal, 48, 99-111. https://doi.org/10.1016/j.pacfin.2018.01.006

Yudhiyati, R., \& Sholihin, M. (2016). Does social disclosure mediate the relationship between contextual variables and financial performance? Empirical evidence on Islamic banks. $\begin{array}{lllll}\text { Jurnal Akuntansi \& } \quad \text { Auditing } & \text { Indonesia, }\end{array}$ https://doi.org/10.20885/jaai.vol20.iss2.art2

\section{Copyrights}

Copyright for this article is retained by the author(s), with first publication rights granted to the journal. This is an open-access article distributed under the terms and conditions of the Creative Commons Attribution license (http://creativecommons.org/licenses/by/4.0/) 